\title{
Foreword: Pathos for Ethics, Business Excellence, Leadership and Quest for Sustainability
}

\author{
Michael Aßländer \\ John Filos \\ Byron Kaldis
}

Ethos, pathos and logos are classical elements of Aristotelian rhetoric. Ethos refers to the personality or trustworthiness of the speaker who expresses herself with integrity and reputation. Logos refers to the internal consistency of reasoning, whereas pathos is an appeal to (the audience's) emotion. Although Aristotle believes that argumentation is crucial for convincing the audience, he sees pathos and ethos as connected elements that if used in a suitable and appropriate manner, express the credibility of the speaker. As Aristotle points out, rhetoric and ethics are interrelated. Pathos, in the classical Greek sense, refers to passion and describes how passionately a person stands up for his or her personal moral convictions.

In the organizational context, this kind of pathos is an indispensable element of (ethical) leadership and a driving force when striving for (business) excellence and (organizational) improvements. Pathos for ethics can influence business life or the way corporations unfold their corporate strategies and conduct their business. However, during the recent economic crisis, it became obvious that ethical passion is missing in many corporations. Not least the crisis was caused by insufficient corporate governance, a lack of sustainable CSR policies, wrong leadership and lacking ethical practice. The crisis has caused uncertainties for consumers, employees and creditors all round the world, has jeopardized the savings of pensioners and small investors and even pension funds. What is more, the financial crisis has unsettled our erstwhile naïve confidence in national sovereignty, seeing how whole countries may be adversely affected. Today, the need for responsible business practice, fair reward policy, stable business relations, job security and sustainable corporate policy are felt more than ever. Ethical reflection becomes a foremost duty of responsible management.

Apart from the emotional elements of character (ethos) and, more generally, the Aristotelian treatment of ethical virtues, Aristotle's other crucial element, that of intellectual virtue, namely phronesis, must also be stressed, especially given the current conditions of financial crisis. It is no accident that Aristotle links that part of the intellect concerning right action with the activities of economics and finance not just once but in several places. Aristotle laid significant emphasis on the excellence appropriate to good or proper deliberation by means of right reasoning that underlies phronesis. Proper deliberation based on logos deals, unlike scientific knowledge of general principles or of unalterable truths, with the contingent elements or means of an action that are alterable. To the extent that recent worrisome developments regarding gross malpractices in the financial sector worldwide cry for the imposition of regulative solutions, one might think that Aristotelian virtue ethics should yield to a deontological type of theories putting forward an analysis in terms of obligation and rights. Nevertheless, far from challenging Aristotelian ethics, the recent malpractices foregrounding gross failure of trust and disrespect for fiduciary values have opened anew discussions regarding the nature of financial agency and the kind of deliberation it must involve. The recent turn of events thus recommend even more strongly an Aristotelian approach of agency based on the exercise of virtuous judgment rather than an ethics based on general principles that need only to be applied. Let us recall that Aristotle does not limit phronesis to simply manipulating means to 
an end, but calls it a kind of correctness in deliberation that seeks or tends towards something good.

Even if well-known theses by some contemporary economists disparaging regulation of financial markets, and especially of derivatives, and other such financial instruments and products churned up by 'financial wizzards', hold true in claiming that financial speculation and inventing of new such instruments have positive social and economic consequences, the need for proper deliberation by means of right reason on the part of those involved in such practices becomes even more indispensable.

This special issue of the Journal of Business Ethics presents selected papers from the 22nd Annual Conference of the European Business Ethics Network (EBEN) held in Athens from 10th to 12th September 2009. Dedicated to the great works of the ancient philosophers the conference bore the title "Pathos for Ethics, Business Excellence, Leadership and Quest for Sustainability" and comprised various perspectives on the virtues of business leaders and on governance in times of economic turmoil.

The present special issue starts with the keynote address of Alejo Sison held in the final plenary session of the conference that is a tribute to Aristotelian political philosophy and his definition of citizenship and citizen rights which also might be fruitful for the recent discussion about corporate citizenship. It is followed by a series of conceptual and empirical works on corporate responsibility. Next come contributions addressing questions on organizational behaviour and corporate governance. Finally, we present some works on ethical finance and the idea of micro-insurances.

As guest editors of this special issue, on behalf of the EBEN Executive Committee we would like to thank all colleagues who agreed to serve as reviewers for the conference as well as for this issue. We especially express our gratitude to the Organizing Committee and our Greek colleagues from Deree College of The American College of Greece for organizing and hosting this 22nd EBEN annual conference. And last but not least, we thank all the participants to the conference who contributed in various workshops and plenary sessions to this unique event at the birthplace of western philosophy.

Let us close this short Foreword with an apt and quite topical reminder of Montesquieu's:

The citizens of ancient Greek-poleis, who lived in a political society of government by the people, did not recognize anything other than virtue as the only force that could support them. Those of today talk of nothing but manufacturing, commerce, finance and fiscal policy, of riches and luxury.

Michael Aßländer International Graduate School Zittau, Zittau, Germany E-mail:michael.asslaender@gmx.de

John Filos

Panteio University, Athens, Greece E-mail: jfilos@hdgf.gr

Byron Kaldis School of Humanities, The Hellenic Open University, Athens, Greece E-mail: bkald@eap.gr 